\title{
Recovery of Zinc from Metallurgic Waste Sludges
}

\author{
Elżbieta Radzymińska-Lenarcik*, Mariusz Sulewski, Włodzimierz Urbaniak
}

Department of Inorganic Chemistry, Faculty of Chemical Technology and Engineering, UTP University of Science and Technology, Seminaryjna 3, 85-326 Bydgoszcz, Poland

Received: 12 August 2014

Accepted: 23 September 2014

\begin{abstract}
Zinc-bearing sludge deposits resulting from metallurgical zinc production have been investigated. They were found to contain $11.0-13.0 \%$ of zinc, $1.4-1.5 \%$ of copper, $1.1-1.3 \%$ of arsenic, and $c a 1 \%$ of lead, plus small amounts of cadmium and nickel ( 0.5 and $0.1 \%$, respectively). The results of the leaching of these deposits with hydrochloric, sulfuric, and lactic acids, as well as with ammonia and $\mathrm{NaOH}$, are presented. The composition of the leachates was dependent on the leaching reagent used. The effectiveness of leaching decreased in the following order of the reagents used: ammonia (10.5\%), $\mathrm{HNO}_{3}$ and $\mathrm{NaOH}(10.0 \%$ each), $\mathrm{H}_{2} \mathrm{SO}_{4}(9.5 \%), \mathrm{HCl}(9.0 \%)$, and lactic acid (8.0\%). Due to the poor selectivity of the strong mineral acids used, the most effective leaching reagents were concentrated ammonia, $\mathrm{NaOH}$, and lactic acid. The recovery of zinc using electrolysis and solvent extraction also was evaluated. As much as $92.0-99.0 \%$ of zinc was deposited on the cathode for a sulfuric acid solution having a $\mathrm{pH}$ in the range 1-2. The extractants used in the extraction process were a $60 \%$ TBP solution in toluene for acidic solutions and 1-decyl-2-methylimidazole for weakly acidic and weakly alkaline solutions. From a solution having a pH of around 2.7, $\mathrm{Zn}$ (II) ions were most effectively extracted (99.0\%), whereas from those of a $\mathrm{pH}>4$, also $\mathrm{Cu}$ (II) and $\mathrm{Cd}$ (II) $(98.5$ and $96.0 \%$, respectively) ions were co-extracted along with $\mathrm{Zn}(\mathrm{II})$. The $\mathrm{Ni}(\mathrm{II})$ ions were most effectively extracted at a $\mathrm{pH}$ around 5.5 (74.0\%). From solutions left after leaching with $\mathrm{NaOH}$, 1-decyl-2-methylimidazole extracted mostly $\mathrm{Zn}$ (II) and $\mathrm{Cu}(\mathrm{II})$, whereas from those left after leaching with ammonia, $\mathrm{Cd}(\mathrm{II})$ could be extracted in addition to $\mathrm{Zn}(\mathrm{II})$ and $\mathrm{Cu}(\mathrm{II})$. An optimum $\mathrm{pH}$ for zinc recovery was 7.5-8.0.
\end{abstract}

Keywords: zinc-bearing sludges, separation of metal ions, heavy metals, zinc recovery

\section{Introduction}

The domestic mining industry of zinc and lead and their metallurgy have a long history. However, nowadays their dwindling resources indicate that in order to continue its existence, this industrial branch will be forced to be based either on imported ores or on recovery of zinc from zincbearing waste. It is also worth emphasizing that zinc has been categorized as a strategic metal $[1,2]$. An irregular increase in demand for metals has been observed since 2004 and, occasionally, the demand surpasses the supply, resulting in soaring prices on the markets. For instance, in

*e-mail: elaradz@utp.edu.pl
2005 the price of $1 \mathrm{Mg}$ of zinc was 1,450 USD, in 2006 it increased up to $4,500 \mathrm{USD}$, while in 2014 it oscillated around 2,300 USD [3]. There is also an increased demand for zinc in various sectors of the economy, including production of anticorrosive coatings in the building and automotive industries.

Nowadays in zinc metallurgy, materials with elevated zinc contents, including copper metallurgy waste, are recycled. However, zinc mills call for materials with zinc contents above $20 \%$ [4]. Consequently, there is a need for the development and search for effective methods of extraction of this costly metal from poorer raw materials.

The literature includes many reports concerning procedures for extraction of zinc and other metals from industri- 
al wastes. The process of zinc recovery depends on the form in which it occurs, on its concentration and degree of contamination [5]. In many reports, solvent extraction has been proposed to selectively recover heavy metals (zinc, copper, cadmium, and nickel) using extractants such as TBP (tributyl phosphate), crown ethers, $\beta$-diketones, carboxylic acids and their derivatives, and imidazole derivatives $[6,7]$. With many zinc-bearing wastes, leaching is a potential method of choice for their processing $[5,8,9]$. Zinc from the leachates can be recovered using various methods, e.g., electrolysis, crystallization, and precipitation of the metal [10].

Zinc can also be separated by selective solvent extraction using an industrial extractant (RH). For extraction from acidic solutions, the extractants used were tributyl phosphate (TBP) [11-13], di(2-ethylhexyl)phosphoric acid (D2EHPA) [12, 14], and a phosphonium ionic liquid [15, 16], for neutral ones containing chlorides - trioctyl amine (TOA) [17] or LIX63 (5,8-diethyl-7-hydroxydodecan-6oxime) [18], while imidazole derivatives were used for solutions left after leaching with ammonia or $\mathrm{NaOH}$ of a $\mathrm{pH}$ of 7-8 [6]. Either extraction naphtha or toluene were used as water-immiscible solvents.

An $(\mathrm{RH})$ extractant transports $\mathrm{Zn}(\mathrm{II})$ ions to the organic phase according to the equation:

$$
2(\mathrm{RH})_{\text {org }}+\mathrm{Zn}^{2+}=\left(\mathrm{R}_{2} \mathrm{Zn}\right)_{\text {org }}+2 \mathrm{H}^{+}
$$

In the next step, during re-extraction with sulfuric acid or ammonia, the extractant can be recovered and zinc extracted into the water phase according to the reaction:

$$
\left(\mathrm{R}_{2} \mathrm{Zn}\right)_{\mathrm{org}}+2 \mathrm{H}^{+}=2(\mathrm{RH})_{\mathrm{org}}+\mathrm{Zn}^{2+}
$$

The objective of our investigations was zinc-bearing sludge deposits originating from hydrometallurgical zinc production after purification of the electrolyte supplied to electrolytic tanks. So far, the wastes have not been utilized, hence our interest in those sludges. In this work, the results of leaching such sludges with acids and bases are present ed. The composition of the leachates was dependent on the leaching agent used. Also, the possibility of zinc deposition from the leachates by electrolysis and elimination of extraneous metals by grouting with zinc metal, as well as the extraction of the metal in the liquid-liquid system, were studied.

The extractant used for acidic solutions was TBP (Fig. 1a), whose effectiveness and utility have been reported in the literature, whereas 1-decyl-2-methylimidazole (Fig. 1b) was used for neutral solutions after neutralization to a $\mathrm{pH}$ of 6-8. a)

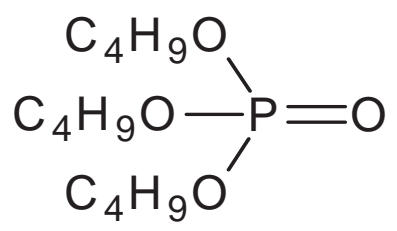

b)

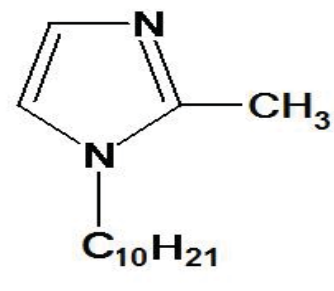

Fig. 1. Structural diagrams of the a) tributyl phosphate, and b) 1-decyl-2-methylimidazole extractants.
Substitution of the methyl group in position 2 of the imidazole ring (Fig. 1b) increases the basicity of a molecule by one order of magnitude $\left(\mathrm{pK}_{\mathrm{a}}=8.44\right)$, compared with that of 1-alkylimidazoles [19]. At the same time, the 2-methyl group provides steric hindrance during complexation with metals and decreases their stability [20]. This weakening of stability due to steric hindrance depends on the type of central ion. The most remarkable decrease in stability has been noticed with octahedral complexes of $\mathrm{Co}(\mathrm{II})$ and $\mathrm{Ni}(\mathrm{II})$ [20]. However, the steric effect caused by the substituent in position 2 does not affect the formation of the $\mathrm{Cu}(\mathrm{II})$ [21] and $\mathrm{Zn}$ (II) complexes [22], because these ions form tetrahedral species that are less prone to steric hindrance. This has been utilized in the separation of ionic mixtures.

1-Decyl-2-methylimidazole was used as the carrier of non-ferrous ions across polymeric inclusion membranes [23].

\section{Experimental}

The sludges to be analyzed are brown clayey solids.

The sludge samples formed a compact (though heterogeneous) mass, which was homogenized. The dry mass content was monitored every three hours using a RADWAG gravimetric drier. The dry weight was determined every three seconds at $105^{\circ} \mathrm{C}$.

\section{Procedures}

\section{Drying of Precipitates}

Before leaching, the sludge was dried. Thus a sample of the sludge was placed in a laboratory drier (WTC Binder 78532 Tuttlingen/Germany) at $105^{\circ} \mathrm{C}$ to a constant weight. The sludge contained approx. $35 \%$ water.

The dry material was then processed as described below.

\section{Mineralization}

Two samples of the sludge were divided into three subsamples each, which were mineralized with a concentrated nitric acid in a MARS 5 (CEM) microwave oven. After mineralization, the solutions were diluted to a defined volume $\left(50 \mathrm{~cm}^{3}\right)$ in which the metal concentrations were determined using the ICP-OES VISTA-MPX (Varian) emission spectrometer.

\section{Leaching}

The following leaching agents were used: $\mathrm{NH}_{3}$ (a 25\% solution, p.a., PChO, Lublin), NaOH (PPCh STANLAB Sp.J: p.a., Lublin), $\mathrm{HCl}$ (a 36\% solution, PPCh, STANLAB, p.a.), $\mathrm{HNO}_{3}$ (a $65 \%$ solution, PPCh STANLAB, p.a.), and lactic acid (POCh, Gliwice, p.a.).

To $c a 0.5$-g samples of the materials, $50 \mathrm{~cm}^{3}$ volumes of each of the following solutions were added: concen- 
Table 1. Metal contents (average values) in the mineralized sludge from hydrometallurgy of zinc.

\begin{tabular}{|c|c|c|c|c|c|c|c|c|}
\hline \multirow{2}{*}{ Sample No. } & \multicolumn{9}{|c|}{ Elements [\%] } \\
\cline { 2 - 10 } & $\mathrm{Zn}$ & $\mathrm{Fe}$ & $\mathrm{As}$ & $\mathrm{Pb}$ & $\mathrm{Cd}$ & $\mathrm{Cu}$ & $\mathrm{Cr}$ & $\mathrm{Ni}$ \\
\hline 1 & $11.43 \pm 0.11$ & $13.23 \pm 0.15$ & $1.2 \pm 0.02$ & $1.01 \pm 0.02$ & $0.36 \pm 0.01$ & $1.41 \pm 0.02$ & $0.32 \pm 0.01$ & $0.11 \pm 0.01$ \\
\hline 2 & $13.1 \pm 0.20$ & $15.4 \pm 0.12$ & $1.32 \pm 0.01$ & $1.14 \pm 0.02$ & $0.39 \pm 0.01$ & $1.55 \pm 0.02$ & $0.35 \pm 0.01$ & $0.12 \pm 0.01$ \\
\hline
\end{tabular}

Table 2. Percentage of metals in solutions left after leaching the sludge.

\begin{tabular}{|c|c|c|c|c|c|c|c|c|}
\hline \multirow{2}{*}{ Leaching reagent } & \multicolumn{8}{|c|}{ Elements [\%] } \\
\hline & $\mathrm{Zn}$ & $\mathrm{Fe}$ & $\mathrm{Cu}$ & $\mathrm{Pb}$ & As & $\mathrm{Cd}$ & $\mathrm{Cr}$ & $\mathrm{Ni}$ \\
\hline Concentrated $\mathrm{NH}_{3}$ & 10.5 & 0.4 & 1.1 & 0.2 & 0.2 & 0.2 & 0.2 & - \\
\hline $30 \% \mathrm{NaOH}$ & 10.0 & - & 0.5 & 0.6 & 0.3 & - & 0.25 & - \\
\hline $2 \mathrm{M} \mathrm{HCl}$ & 9.0 & 12.0 & 0.6 & 0.1 & 0.1 & 0.3 & 0.3 & 0.1 \\
\hline $2 \mathrm{M} \mathrm{HNO}_{3}$ & 10.0 & 13.0 & 1.0 & 1.0 & 1.0 & 0.4 & 0.3 & 0.1 \\
\hline $2 \mathrm{M} \mathrm{H}_{2} \mathrm{SO}_{4}$ & 9.5 & 11.0 & 1.2 & - & 0.05 & 0.3 & 0.3 & 0.1 \\
\hline $80 \%$ Lactic acid & 8.0 & 1.5 & 1.0 & 0.1 & - & 0.1 & 0.3 & 0.1 \\
\hline
\end{tabular}

trated $\mathrm{NH}_{3}, 30 \% \mathrm{NaOH}, 2 \mathrm{M} \mathrm{HCl}, 2 \mathrm{M} \mathrm{H}_{2} \mathrm{SO}_{4}$, and $80 \%$ lactic acid. The mixtures were shaken for $\mathrm{ca} 1 \mathrm{hr}$ and left to stand for $24 \mathrm{hrs}$. Then they were filtered into measuring flasks.

\section{Determination of Metals Concentration}

The metal concentrations in the leachates were determined on the ICP-OES VISTA-MPX (Varian) emission spectrometer in a WASTE LAB Instrumental Analysis Laboratory in Poznan, Poland.

\section{Cementation}

Zinc metal was added to the solutions left after leaching and the samples were placed in a thermostatted water bath shaker (ELPAN type 357) until equilibrium was attained (no longer than $10 \mathrm{hrs}$ ). In the water bath, the temperature was held at $25^{\circ} \mathrm{C}$.

\section{Solvent Extraction}

The extractants used were: a $60 \%$ TBP (tributyl phosphate) (Fluka) solution in toluene (POCh, Gliwice; p.a.) for solutions left after leaching with acids, and 1-decyl-2methylimidazole (synthesized according to a method reported in the literature [24]) in toluene for basic solutions.

Test tubes with two immiscible liquids were shaken on a thermostatted shaker at $25^{\circ} \mathrm{C}$ until equilibrium was attained (no longer than $30 \mathrm{~min}$ ). Then the phases were separated, the $\mathrm{pH}$ of the water phase was measured, and the metal concentrations were determined.

\section{Electrolysis}

The purified electrolyte was acidified with sulfuric acid and electrolyzed in a Chemical Analysis Apparatus EP-4 (Nysa, Poland), at $32-37^{\circ} \mathrm{C}$, at a current density of 3-7 $\mathrm{A} / \mathrm{dm}^{2}$. Aluminum was used as the cathode, and lead as the anode.

\section{Discussion of Results}

\section{Mineralization of Sludges}

Preliminary data on the composition of the sludge obtained after mineralization are shown in Table 1. Table 1 contains the average values and standard deviations.

The sludge contained $11-13 \%$ of zinc, ca $1.4-1.5 \%$ of copper, $1.1-1.3 \%$ of arsenic, ca $1 \%$ of lead, and small amounts of cadmium and chromium ( $c a 0.5 \%$ each), and nickel (ca $0.1 \%)$.

\section{Leaching of Sludges from the Hydrometallurgy of Zinc}

The percentages of metals determined after leaching with various solvents are shown in Table 2.

Apart from zinc, the sludge contained also $\mathrm{As}, \mathrm{Cd}, \mathrm{Cr}$, $\mathrm{Cu}, \mathrm{Fe}, \mathrm{Ni}$, and $\mathrm{Pb}$. The metal contents varied depending on the leaching reagent used, due to different mechanisms of the process (see below). However, in each case zinc was leached, its content ranging from 8 to $10.5 \%$. The greatest amounts of the metal were leached with solutions of ammonia and $\mathrm{NaOH}$. 


\section{Leaching with Acids}

During the sludge leaching with hydrochloric acid, the following reactions took place:

$$
\begin{gathered}
\mathrm{ZnO} \cdot \mathrm{Fe}_{2} \mathrm{O}_{3}+8 \mathrm{HCl}=\mathrm{ZnCl}_{2}+2 \mathrm{FeCl}_{3}+4 \mathrm{H}_{2} \mathrm{O} \\
\mathrm{ZnO}+\mathrm{HCl}=\mathrm{ZnCl}_{2}+\mathrm{H}_{2} \mathrm{O}
\end{gathered}
$$

Apart from zinc, during the leaching with acids the following ions also can be leached: $\mathrm{Cd}(\mathrm{II}), \mathrm{As}(\mathrm{III}), \mathrm{Cr}(\mathrm{III})$, $\mathrm{Cu}(\mathrm{II}), \mathrm{Fe}(\mathrm{III}), \mathrm{Ni}(\mathrm{II})$, and $\mathrm{Pb}$ (II) (although the last-named ion forms a sparingly soluble chloride $\mathrm{PbCl}_{2}$, hence its amount in the filtrate was negligible).

Similar processes occurred when $\mathrm{HNO}_{3}, \mathrm{H}_{2} \mathrm{SO}_{4}$, and lactic acid were used. However, during the leaching with sulfuric acid, $\mathrm{Pb}$ (II) could not be detected in the filtrate because it forms a sparingly soluble $\mathrm{PbSO}_{4}$.

During the leaching with lactic acid, first of all $\mathrm{Zn}(\mathrm{II})$ was present in the filtrate, together with small amounts of $\mathrm{Fe}(\mathrm{III})$ and $\mathrm{Cu}(\mathrm{II})$, while $\mathrm{As}(\mathrm{III})$ was not present at all.

\section{Leaching with $\mathrm{NaOH}$}

In basic solutions, zinc compounds readily form hydroxocomplexes according to the reaction:

$$
\mathrm{ZnO}+\mathrm{H}_{2} \mathrm{O}+2 \mathrm{OH}^{-}=\left[\mathrm{Zn}(\mathrm{OH})_{4}\right]^{2-}
$$

...which are solubilized together with $\mathrm{As}(\mathrm{III}), \mathrm{Cu}(\mathrm{II})$, $\mathrm{Cr}(\mathrm{III})$, and $\mathrm{Pb}(\mathrm{II})$, which were detected by spectrophotometry.

\section{Leaching with Ammonia}

Leaching with ammonia occurs according to the reaction:

$$
\left.\mathrm{Me}^{2+}+4 \mathrm{NH}_{3(\mathrm{aq})}=\left[\mathrm{MeNH}_{3}\right)_{4}\right]^{2+}
$$

\section{Summary of the Leaching Process}

Trace amounts $(0.1 \%)$ of $\mathrm{Ni}$ were found in solutions left after leaching with $0.03 \% \mathrm{HCl}$ and $0.02 \% \mathrm{HNO}_{3}$ solutions. Also, small amounts of $\mathrm{Cr}$ and $\mathrm{Cd}(0.1-0.4 \%)$ were found, the highest of them ( 0.4 and $0.3 \%$, respectively) were detected in the samples leached with nitric acid. The highest amounts of the $\mathrm{Pb}$ (II) ions (1\%) were extracted with $\mathrm{HNO}_{3}$, whereas in the remaining leachates its content was negligible $(0-0.6 \%)$. With the exception of the $10 \% \mathrm{NaOH}$, $\mathrm{Fe}$ was found in all leaching solutions. Its content was higher than $10 \%$ in leachates containing strong acids. Most of the leachates contained $c a 1 \%$ of $\mathrm{Cu}(\mathrm{II})$. With the exception of the $1 \% \mathrm{HNO}_{3}$ solution, the content of arsenic in the remaining solutions was low, ranging from $0 \%$ in lactic acid to $0.3 \%$ in $30 \% \mathrm{NaOH}$.

Concentrated ammonia leached mostly zinc and copper, the amounts of the former being 10-fold higher than those of copper. Lactic acid turned out to be quite interesting. $\mathrm{Zn}$ $(8 \%), \mathrm{Fe}(1.5 \%)$, and $\mathrm{Cu}(1 \%)$ prevailed in its solutions.
As far as the effectiveness of zinc extraction is concerned, the leaching solutions can be arranged in the following order: $\mathrm{NH}_{3}$ (10.5\%), $2 \mathrm{M} \mathrm{HNO}_{3}$ and $30 \% \mathrm{NaOH}$ (10\% each), $2 \mathrm{M} \mathrm{H}_{2} \mathrm{SO}_{4}$ (9.5\%), $2 \mathrm{M} \mathrm{HCl}(9 \%)$, and lactic acid $(6 \%)$. However, due to the poor selectivity of the strong acids, $2 \mathrm{M} \mathrm{HCl}, 2 \mathrm{M} \mathrm{HNO}_{3}$ and $2 \mathrm{M} \mathrm{H}_{2} \mathrm{SO}_{4}$, concentrated $\mathrm{NH}_{3}, 30 \% \mathrm{NaOH}$, and $80 \%$ lactic acid were the most effective extractants.

\section{Recovery of Zinc from the Leachates}

\section{Electrolysis}

Before electrolytic deposition of zinc from the leachates, the following ions were removed:

a) $\mathrm{Fe}(\mathrm{II})$, which was oxidized by the following reaction:

$$
2 \mathrm{Fe}^{2+}+\mathrm{MnO}_{2}+4 \mathrm{H}_{3} \mathrm{O}+=2 \mathrm{Fe}^{3+}+\mathrm{Mn}^{2+}+6 \mathrm{H}_{2} \mathrm{O}
$$

Then Fe(III) was precipitated in the form of basic ferric and sodium sulfate (jarosite):

$$
\begin{gathered}
3 \mathrm{Fe}_{2}\left(\mathrm{SO}_{4}\right)_{3}+\mathrm{Na}_{2} \mathrm{SO}_{4}+12 \mathrm{H}_{2} \mathrm{O}= \\
2 \mathrm{NaFe}_{3}\left(\mathrm{SO}_{4}\right)_{2}(\mathrm{OH})_{6}+6 \mathrm{H}_{2} \mathrm{SO}_{4}
\end{gathered}
$$

b) Ions of more positive metals, $\mathrm{Cu}(\mathrm{II}), \mathrm{Pb}(\mathrm{II}), \mathrm{Ni}(\mathrm{II})$, and $\mathrm{Cd}(\mathrm{II})$ were removed by cementation with zinc powder. The rate of chemical digestion is slow and does not compete with the progress of cementation:

$$
\mathrm{Me}^{2+}+\mathrm{Zn}^{0}=\mathrm{Me}^{0}+\mathrm{Zn}^{2+}
$$

The deposited metals, along with any unreacted zinc, were filtered off. During electrolysis of the solutions acidified with sulfuric acid to a $\mathrm{pH}$ in the range $1-2,92-99 \%$ of zinc was deposited on the cathode.

\section{Solvent Extraction}

A percentage extraction $(\% \mathrm{E})$ of each metal was calculated from the following equation:

$$
\% E=\frac{C_{M}}{C_{M}^{0}} * 100 \%
$$

...where $C_{M}$ and $C_{M}^{0}$ denote metal concentration at an equilibrium in the water phase and an initial metal concentration in that phase, respectively.

The extractant binds metal ions and transfers them to the organic phase according to the equation:

$$
2(\mathrm{RH})_{\text {org }}+\mathrm{Me}^{2+}=\left(\mathrm{R}_{2} \mathrm{Me}\right)_{\text {org }}+2 \mathrm{H}^{+}
$$

It is observed that zinc(II) ions $(99.0 \%)$ were effectively extracted from acidic solutions (Table 3 ) of a $\mathrm{pH}$ around 2.7; $\mathrm{Cu}(\mathrm{II})(98.5 \%)$ and $\mathrm{Cd}(\mathrm{II})(96.0 \%)$ ions were effectively extracted from solutions of $\mathrm{pH}>4$ along with $\mathrm{Zn}(\mathrm{II})$; whereas $\mathrm{Ni}(\mathrm{II})$ were most effectively extracted at a $\mathrm{pH}$ around $5.5(74.0 \%)$.

Iron(III) ions, of which the concentration in solutions after leaching with acids is considerable, are complexed 
Table 3. Percentage recovery of the metals during extraction with an $80 \%$ TBP solution in toluene from solutions after leaching with acids.

\begin{tabular}{|c|c|c|c|c|c|c|}
\hline $\mathrm{pH}$ & $\% \mathrm{Zn}$ & $\% \mathrm{Cu}$ & $\% \mathrm{Cd}$ & $\% \mathrm{Cr}$ & $\% \mathrm{Ni}$ & $\% \mathrm{~Pb}$ \\
\hline \multicolumn{7}{|c|}{ Leaching with hydrochloric acid } \\
\hline 0.86 & 45.0 & 40.0 & 37.0 & 20.0 & 35.0 & - \\
\hline 1.95 & 91.0 & 72.0 & 58.0 & 38.5 & 53.0 & - \\
\hline 2.92 & 98.2 & 88.0 & 81.0 & 50.0 & 69.0 & - \\
\hline \multicolumn{7}{|c|}{ Leaching with sulfuric acid } \\
\hline 0.56 & 40.0 & 35.0 & 30.0 & 15.0 & 22.0 & - \\
\hline 1.72 & 89.5 & 66.0 & 58.0 & 36.0 & 43.0 & - \\
\hline 2.78 & 99.0 & 87.0 & 82.0 & 60.0 & 48.0 & - \\
\hline \multicolumn{7}{|c|}{ Leaching with lactic acid } \\
\hline 4.43 & 90.0 & 95.0 & 91.1 & 63.0 & 70.0 & 75.0 \\
\hline 5.52 & 94.5 & 97.0 & 94.0 & 60.0 & 74.0 & 60.0 \\
\hline 6.37 & 95.2 & 98.5 & 96.0 & 54.0 & 67.0 & 51.5 \\
\hline
\end{tabular}

Table 4. Percentage recoveries of the metals during extraction with 1-decyl-2-methylimidazole solution in toluene from solutions after leaching with $\mathrm{NaOH}$ or ammonia.

\begin{tabular}{|c|c|c|c|c|c|}
\hline $\mathrm{pH}$ & $\% \mathrm{Zn}$ & $\% \mathrm{Cu}$ & $\% \mathrm{Cd}$ & $\% \mathrm{Cr}$ & $\% \mathrm{~Pb}$ \\
\hline \multicolumn{5}{|c|}{ Leaching with $\mathrm{NaOH}$} \\
\hline 6.85 & 76.0 & 84.0 & - & 42.0 & 48.0 \\
\hline 7.23 & 85.9 & 90.0 & - & 45.0 & 53.0 \\
\hline 7.59 & 97.7 & 93.0 & - & 50.0 & 57.5 \\
\hline 7.96 & 98.3 & 95.0 & - & 54.0 & 63.0 \\
\hline 8.35 & 96.3 & 95.0 & - & 56.0 & 67.0 \\
\hline \multicolumn{7}{|c|}{ Leaching with ammonia } \\
\hline 6.20 & 69.0 & 72.0 & 63.0 & 35.0 & 45.0 \\
\hline 6.67 & 75.0 & 80.0 & 67.0 & 38.0 & 48.0 \\
\hline 7.12 & 90.5 & 88.0 & 74.0 & 40.0 & 52.0 \\
\hline 7.58 & 98.0 & 94.0 & 76.0 & 42.0 & 60.0 \\
\hline 7.91 & 99.0 & 96.0 & 78.0 & 47.0 & 64.0 \\
\hline
\end{tabular}

with TBP (extractant) and undergo extraction together with other metals into the organic phase. On the other hand, $\mathrm{Fe}$ (II) cannot be complexed with TBP. To prevent its transfer by dibutylphosphoric acid (a product of partial hydrolysis of TBP), the hydrolysis products must be removed, for instance, by washing the organic phase with a dilute $\mathrm{NaOH}$ solution or ammonia.

$\mathrm{Fe}$ (III) ions could also be eliminated by reduction, for instance by passing the solution through a steel-woolpacked column. However, the operation provides an addi- tional step, hence it seems more desirable to use extraction with 1-decyl-2-methylimidazole of the solution after leaching with $\mathrm{NaOH}$ or ammonia (Table 4).

After leaching with $\mathrm{NaOH}, 1$-decyl-2-methylimidazole extracts mainly $\mathrm{Zn}$ (II) and $\mathrm{Cu}$ (II) ions, whereas after leaching with ammonia, large amounts of Cd(II) were found in addition to $\mathrm{Zn}(\mathrm{II})$. The recovered amount of copper increases with an increase in the $\mathrm{pH}$ of the water phase. An optimum $\mathrm{pH}$ for the recovery of zinc is in the range 7.38.0.

\section{Conclusions}

The content of zinc in the sludge is high enough (10$13 \%$ ) to justify its recovery by hydrometallurgical techniques.

As far as the efficiency of leaching zinc is concerned, the solutions used can be arranged in the following order: $\mathrm{NH}_{3}(10.5 \%), 2 \mathrm{M} \mathrm{HNO}_{3}$ and $30 \% \mathrm{NaOH}$ (10\% each), $2 \mathrm{M}$ $\mathrm{H}_{2} \mathrm{SO}_{4}(9.5 \%), 2 \mathrm{M} \mathrm{HCl}(9 \%)$, and lactic acid (8\%). However, due to the poor selectivity of strong acids (2M $\mathrm{HCl}, 2 \mathrm{M} \mathrm{HNO}_{3}$, and $2 \mathrm{M} \mathrm{H}_{2} \mathrm{SO}_{4}$ ), the most effective leaching solutions were: the concentrated ammonia, $30 \% \mathrm{NaOH}$, and $80 \%$ lactic acid.

Zinc from the leachates can be recovered using:

- Electrolysis $(92-99 \%$ of the metal is deposited on the cathode)

- Solvent extraction (by using either TBP as the extractant for solutions of a $\mathrm{pH}$ around 2.7-efficiency being 99\%-, or by using 1-decyl-2-methylimidazole at a $\mathrm{pH}$ of 7.5-8.0 with an efficiency of $96-99 \%$.

\section{References}

1. CHOLEWA E., LUTZE R., KWIATKOWSKI L., OKUROWSKI W. Electrolytic zinc alloy coating - development and application. Inżynieria Powierzchni, Wyd. Instytut Mechaniki Precyzyjnej, Warszawa, 2007 [In Polish].

2. MILEWSKI W., KOBUS J. Sample analysis of the operating costs of anti-corrosion coatings. Inżynieria Powierzchni, Wyd. Instytut Mechaniki Precyzyjnej, Warszawa, 2010 [In Polish].

3. Prices according to the London Metal Exchange quotations: $\mathrm{http} /$ www.infomine.com/investment/metal-prices/zinc/5-year/

4. KUCHARSKI M. Non-ferrous metal recycling. Kraków 2010 [In Polish].

5. DE SOUZA A.D., PINA P.S., LEÃO V.A. Bioleaching and chemical leaching as an integrated process in the zinc industry. Min. Eng. 20, 591, 2007.

6. RADZYMINSKA-LENARCIK E., URBANIAK W. The use of liquid-liquid extraction in the concentration and recovery of metals from waste. Municipal Waste Management, Wyd. Politechniki Koszalińskiej, IX, 2013.

7. SZYCZEWSKI P., SIEPAK J., NIEDZIELSKI P., SOBCZYŃSKI T. Research on heavy metals in Poland. Pol. J. Environ. Stud. 18, 755, 2009.

8. XU H., WEI CH., LI C., FAN G., DENG Z., ZHOU X., QIU S. Leaching of a complex sulfidic, silicate-containing zinc ore in sulfuric acid solution under oxygen pressure. Sep. Purif. Technol. 85, 206, 2012. 
9. RADZYMINSKA-LENARCIK E., URBANIAK W Studies on leaching of sludge arising in copper production in order to recover zinc. Municipal Waste Management, Wyd. Politechniki Koszalińskiej, vol. X, 2014.

10. DEEPA A., DE CARVALHO J.M.R. Review on the recent developments in the solvent extraction of zinc. Solv.Ext. Ion Exch. 26, 375, 2008.

11. KUJAWSKI W., BOGACKI M. Molecular dynamics study of the behaviour of TBP-zinc-chloride complex at the chloroform/water interfacial system. Sep. Sci. Technol. 47, 1285, 2012.

12. HAGHSHENAS FATMEHSARIA D., DARVISHIB D., ETEMADIC S., EIVAZI HOLLAGHB A.R., KESHAVARZ ALAMDARIA E., SALARDINIB A.A. Interaction between TBP and D2EHPA during $\mathrm{Zn}, \mathrm{Cd}, \mathrm{Mn}$, $\mathrm{Cu}, \mathrm{Co}$ and $\mathrm{Ni}$ solvent extraction. Hydrometallurgy 98, (12), 143, 2009.

13. SARANGI K., PARHI P.K., PADHAN E., PALAI A.K., NATHSARMA K.C., PARK K.H. Separation of iron(III), copper(II) and zinc(II) from a mixed sulphate/chloride solution using TBP, LIX 84I and Cyanex 923. Sep. Purif. Technol. 55, 44, 2007.

14. GHARABAGHI M., IRANNAJAD M., AZADMEHR A.R Separation of nickel and zinc ions in a synthetic acidic solution by solvent extraction using D2EHPA and Cyanex 272. Physicochem. Probl. Miner. Process. 49, 233, 2013.

15. REGEL-ROSOCKA M., NOWAK L., WISNIEWSKI M. Removal of zinc(II) and iron ions from chloride solutions with phosphonium ionic liquids. Sep. Purif. Technol. 97, 158, 2012.

16. REGEL-ROSOCKA M., WISNIEWSKI M. Selective removal of zinc(II) from spent pickling solutions in the presence of iron ions with phosphonium ionic liquid Cyphos IL 101. Hydrometallurgy 110, 85, 2011.
17. LVAB Y., JIAAC Y., ZHANGAB CH., CUIAB Z., LINC P., JIANGC X., JINGA Y. Extraction of Chloride Ions from Zinc-Bearing Waste Lixivium by Trioctyl Amine (TOA). Sep. Sci. Technol. 49, 1192, 2014.

18. ZHU Z., ZHANG W., PRANOLO Y., CHENG C.Y. Separation and recovery of copper, nickel, cobalt and zinc in chloride solutions by synergistic solvent extraction. Hydrometallurgy 127, 1, 2012.

19. LENARCIK B., OJCZENASZ P. The influence of the size and position of the alkyl groups in alkylimidazole molecules on their acid - base properties. J. Heterocycl. Chem. 39, 287, 2002.

20. RADZYMINSKA-LENARCIK E. Search for the possibility of utilizing the differences in complex-forming capacities of alkylimidazoles for selective extraction of some metal ions from aqueous solutions. Pol. J. Chem. Technol. 10, (1), 73, 2008.

21. RADZYMINSKA-LENARCIK E. Effect of alkyl chain length on the extraction of copper(II) complexes with 1alkyl-2-methylimidazoles. Sep. Sci. Technol. 42, 2661, 2007.

22. LENARCIK B., KIERZKOWSKA A. The influence of alkyl chain length and steric effect on extraction of zinc(II) complexes with 1-alkyl-2-methylimidazoles. Solv. Ext. Ion Exch. 24, 433, 2006.

23. ULEWICZ M., RADZYMINSKA-LENARCIK E. Application of supported and polymer membrane with 1decyl-2-methylimidazole for separation of transition metal ions. Physicochem. Probl. Miner. Process. 48, 91, 2012.

24. PERNAK J., KRYSINSKI J., SKRZYPCZAK A. Bactericidal aluminum compounds. A. Tenside Surfact. Det., 24, 276, 1987 [In German]. 